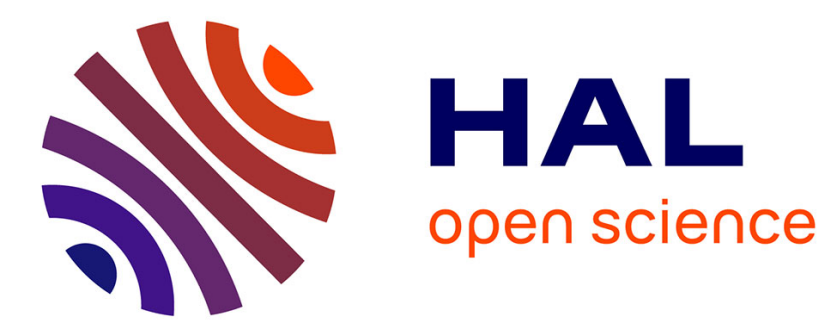

\title{
Variation of reproductive success in a haplo-diploid Red Alga, Gracilaria Verrucosa : effects of parental identities and crossing distance
}

Sophie Richerd, Christophe Destombe, Joël Cuguen, Myriam Valero

\section{- To cite this version:}

Sophie Richerd, Christophe Destombe, Joël Cuguen, Myriam Valero. Variation of reproductive success in a haplo-diploid Red Alga, Gracilaria Verrucosa : effects of parental identities and crossing distance. American Journal of Botany, 1993, 80 (12), pp.1379-1391. 10.2307/2445666 . hal-02020448

\section{HAL Id: hal-02020448 \\ https://hal.science/hal-02020448}

Submitted on 15 Feb 2019

HAL is a multi-disciplinary open access archive for the deposit and dissemination of scientific research documents, whether they are published or not. The documents may come from teaching and research institutions in France or abroad, or from public or private research centers.
L'archive ouverte pluridisciplinaire HAL, est destinée au dépôt et à la diffusion de documents scientifiques de niveau recherche, publiés ou non, émanant des établissements d'enseignement et de recherche français ou étrangers, des laboratoires publics ou privés. 
Variation of Reproductive Success in a Haplo-Diploid Red Alga, Gracilaria verrucosa: Effects of Parental Identities and Crossing Distance

Author(s): Sophie Richerd, Christophe Destombe, Joel Cuguen and Myriam Valero

Source: American Journal of Botany, Vol. 80, No. 12 (Dec., 1993), pp. 1379-1391

Published by: Botanical Society of America, Inc.

Stable URL: http://www.jstor.org/stable/2445666

Accessed: 27-06-2016 10:40 UTC

Your use of the JSTOR archive indicates your acceptance of the Terms \& Conditions of Use, available at

http://about.jstor.org/terms

JSTOR is a not-for-profit service that helps scholars, researchers, and students discover, use, and build upon a wide range of content in a trusted digital archive. We use information technology and tools to increase productivity and facilitate new forms of scholarship. For more information about JSTOR, please contact support@jstor.org.

Botanical Society of America, Inc. is collaborating with JSTOR to digitize, preserve and extend access to American Journal of Botany 


\title{
VARIATION OF REPRODUCTIVE SUCCESS IN A HAPLO-DIPLOID RED ALGA, GRACILARIA VERRUCOSA: EFFECTS OF PARENTAL IDENTITIES AND CROSSING DISTANCE ${ }^{1}$
}

\author{
Sophie Richerd, ${ }^{2,4}$ Christophe Destombe, ${ }^{2}$ \\ JoËl Cuguen, ${ }^{2,3}$ AND Myriam VALERO ${ }^{2}$ \\ ${ }^{2}$ Laboratoire de Génétique et Evolution des Populations Végétales, URA CNRS 1185, GDR CNRS 1002, \\ Université des Sciences et Techniques de Lille, 59655 Villeneuve d'Ascq CEDEX, France; and \\ ${ }^{3}$ Institut Agricole et Alimentaire de Lille, Université des Sciences et Techniques de Lille, \\ 59655 Villeneuve d'Ascq CEDEX, France
}

\begin{abstract}
The factors influencing reproductive success in a haplo-diploid marine alga, Gracilaria verrucosa, have been determined through single-male crosses in the laboratory. Crossing success was assessed by measuring its early components, fertility, and abortion rate. The effects of the male or female parent identity, of the male $\times$ female interaction, and of the geographical distance between mates were tested in crosses within or between populations at different geographical scales. The identity of the female parent has a predominant effect on crossing success. Interparent distance has no effect in within-population crosses; this strongly suggests an absence of inbreeding depression, expected in a species where the haploid phase is individualized and isomorphic to the diploid one. Crossing success tends to increase with distance between mates in betweenpopulation crosses. This heterosis effect seems to indicate that the marine environment could allow genetic divergence between populations, even at short distances (about $100 \mathrm{~m}$ ).
\end{abstract}

The amount of gene flow in plant species is tightly linked with the reproductive and dispersal systems. It is a parameter of great evolutionary importance in determining the level and pattern of genetic differentiation of populations, and therefore the possibility of local adaptation (Wright, 1943). Dispersal in plants is usually philopatric and leptokurtic (Levin and Kerster, 1974; Shields, 1982). The consequence of a limited gene flow is to produce a substructured population with a negative correlation between interplant distance and genetic relatedness (Price and Waser, 1979; Levin, 1984; Fenster and Sork, 1988; Fenster, 1991b). This strong genetic substructure promotes genetic adaptation to various environmental conditions, even at a small geographic scale (Antonovics, 1968; Valero and Olivieri, 1985; Waser and Price, 1985; Ducousso et al., 1990).

Evidence that crossing success may be influenced by parental factors is widespread in plants (reviews in Charlesworth, Schemske, and Sork, 1987; Queller, 1987; Lyons et al., 1989; Marshall and Folsom, 1991). The possible sources of variation of reproductive success are the female identity effect, the male identity effect, or the male $\times$ female interaction effect. Among these, the effect of the genetic relatedness between parents is of particular interest. Crossing success and interparental genetic distance can be positively or negatively related. Parents that are too similar genetically may suffer from reduced cross-

${ }^{1}$ Received for publication 1 December 1992; revision accepted 16 July 1993.

The authors thank Martine Hossaert-McKey, Doyle McKey, Henk Van Dijk, and Philippe Vernet for careful reading of the manuscript; José Godin for discussion and field expeditions; and the two reviewers for useful comments and constructive criticism. This work was supported by CNRS-IFREMER GCS "Bases biologiques de l'Aquaculture" (funds DR17 519204), and MRT grant 89329 to SR.

${ }^{4}$ Author for correspondence. ing compatibility due to inbreeding depression (Levin, 1984, 1989a, b; Charlesworth and Charlesworth, 1987; Johnston, 1992), whereas crosses between parents that are too different genetically may lead to an outbreeding depression by disrupting adaptive complexes (Antonovics, 1968; Price and Waser, 1979; Shields, 1982; Waser and Price, 1983, 1989; Parker, 1992). An intermediate optimal outcrossing distance is therefore expected as a compromise between inbreeding depression and outbreeding depression, and can be found when individuals separated by increasing distance are crossed (Price and Waser, 1979; Waser and Price, 1983, 1989, 1991a; Waser et al., 1987; Sobrevila, 1988; McCall, Mitchell-Olds, and Waller, 1991).

Although they lead to a variety of results, these problems are intensively studied in higher plants; yet they are quite ignored in algae, whose particular features (marine environment, life cycle) give rise to interesting questions. First, the evolutionary consequences of a marine environment are poorly known: dispersal distances and amount of gene flow in the sea have been rarely studied (Santelices, 1990; Destombe et al., 1992), and as a consequence the degree of reproductive isolation between populations, the possibility of local adaptation, and the speciation rates of marine organisms are largely speculative questions (Russell, 1986; Palumbi, 1992). Second, some algae display complex life cycles, involving an alternation of possibly isomorphic haploid and diploid individuals. The consequences of such cycles for the reproductive system have been little studied experimentally (Hawkes, 1990; Valero et al., 1992). In particular, inbreeding depression should be reduced in an isomorphic haplo-diploid life cycle: as the same genes are likely to be expressed in the two phases, deleterious mutations are removed from the genome during the haploid phase (Bernstein et al., 1985; Charlesworth and Charlesworth, 1992).

Here, we investigate the pattern of crossing compatibility found in a haplo-diploid red alga, Gracilaria ver- 
rucosa. Male gamete dispersal in this species is leptokurtic and limited to less than $100 \mathrm{~m}$ in the field (Destombe, Godin, and Remy, 1990). Potential dispersal distance of diploid spores is expected to be small (Destombe et al., 1992), and it has been shown in many algal species that dispersal range is limited to a maximum of between 10 and $100 \mathrm{~m}$ (Santelices, 1990). In these conditions, we expect gene flow to be reduced between populations, genetic similarity to increase among individuals of the same population, and local adaptation to occur in populations submitted to different environments, e.g., different tidal levels.

In this study we first investigate male, female, and male $\times$ female interaction effects on reproductive success, and then look at crossing compatibility between individuals separated by increasing geographic distance, either belonging to the same population or to different close or distant populations. Number of fertilizations and abortion rate were measured in single-male crosses in laboratory conditions, as estimates of prezygotic and early postzygotic compatibility between mates. Additional crosses were performed between individuals from different regions, to test differential reproductive success on a wider geographic scale.

\section{MATERIALS AND METHODS}

Study organism - Gracilaria verrucosa (Huds.) Papenfuss (Gracilariales, Rhodophyta) is a haplo-diploid red alga, with a worldwide distribution. Haploid and diploid individuals are isomorphic and coexist in populations. The individuals consist of a perennial holdfast fixed to the substratum, bearing branched spaghettilike thalli. Haploid individuals are dioecious and produce gametes by mitosis. Mature male individuals bear small sexual crypts on large parts of the thallus, that liberate a large number of small nonpigmented and nonflagellated spermatia (Yamanouchi, 1906; Fredericq and Hommersand, 1989). Female thalli bear uniformly distributed gametangia, which consist of three cells and can be observed only on thallus sections under microscope (Kling and Bodard, 1987). Fertilization occurs on the female individual and involves complex cytological events, resulting in the formation of a cystocarp on the female (Hommersand and Fredericq, 1990). The development of a haploid pericarp is induced, within which the zygote divides mitotically, protected and nurtured by the female. After 3 weeks of maturation the cystocarp liberates thousands of diploid spores (Lefebvre, Destombe, and Godin, 1987; Fredericq and Hommersand, 1989). In some cases, the zygote does not divide normally and gives a pseudocystocarp. This cystocarplike swelling does not produce viable spores (McLachlan, van der Meer, and Bird, 1977; Plastino and de Oliveira, 1988; Destombe, Godin, and Remy, 1990) and will be considered as a postzygotic incompatibility between mates.

Study sites - Geographical location - For within-region crosses, male and female individuals were sampled and mapped in four populations located at two sites in northern France (Pas-de-Calais, on North Sea and Channel coasts). At each of these two sites (Audresselles and Cape Gris-Nez), two populations were chosen at the two ex- tremes of the intertidal range of the species, to maximize their environmental difference. High and low populations were noted as $\mathrm{Gh}$ and $\mathrm{Gl}$ in Gris-Nez, and as $\mathrm{Ah}$ and $\mathrm{Al}$ in Audresselles, respectively. Individuals of the same population are $0.5 \mathrm{~m}$ to $25 \mathrm{~m}$ apart, high and low populations of the same site are approximately $100 \mathrm{~m}$ apart (50 to 70 $\mathrm{m}$ in Gris-Nez and $150 \mathrm{~m}$ in Audresselles due to the difference of slope of the shore in both sites), and the two sites (Audresselles and Gris-Nez) are $3 \mathrm{~km}$ apart.

For between-regions crosses, additional samples were taken from two other French localities: Roscoff (Brittany) and Bouzigues (Etang de Thau, a lagoon connected to the Mediterranean Sea). Each locality is about $1,000 \mathrm{~km}$ from the others.

Environmental characteristics-Ecological conditions differ among the three regions. In Audresselles and Gris$\mathrm{Nez}$, populations are located in rocky pools. Individuals are fixed to the substratum and range from lower to midintertidal level of the shore (Destombe et al., 1989). High and low populations are subjected to different tide and light conditions. In Roscoff, individuals are fixed to small pebbles and drift with strong tidal movements, thus experiencing different tidal level conditions during their lifetime. In Bouzigues, individuals are attached to the substrate just beneath the water surface in the lagoon. They are deprived of tidal fluctuations and are submitted to higher light intensity, temperature, and salinity levels than in the two other sites.

Crossing experiments - Crossing method-Female thalli were sampled in the field in March 1991, at the beginning of the season of growth and reproduction (from March to September; Destombe et al., 1989) and grown in culture for 3 months (filtered sea water, natural light conditions) to obtain virgin new-grown branches (Destombe, Godin, and Remy, 1990). Males were sampled in the same locations in June 1991, just before performing the crosses. Two 10-cm fragments of new grown thallus from one female and two $1-\mathrm{cm}$ fragments of mature thallus from one male were put together in a tube with filtered sea water and periodically shaken (see method in Destombe, Godin, and Remy, 1990). Males were removed after 1 month. The total length of each female fragment was measured 1 month later, and the total number of cystocarps was counted. The occurrence of spores in each cystocarp was determined under the microscope.

Another series of crosses was performed at a later date, in September 1991, after a longer culture period. This series included only individuals that had served for the fourth set of crosses (see below).

As a control for parthenogenesis and virginity, a fragment of each female individual was isolated from the males and grown in the same experimental conditions. No cystocarps were observed in these controls.

Experimental design-As the number of crosses that can be performed with one female is limited by its available length of new-grown thallus, we chose to perform four independent sets of crosses to test different effects (cross design described in the Appendix).

The first set concerns within-population crosses. It was designed to test male and female identity effects, and male 
$x$ female interaction effects. The same design was replicated in two Northern populations (yielding two independent data sets).

The second set of crosses was performed between individuals from two populations from the same site located at different tidal levels to test the magnitude of reproductive isolation that might be due to ecotypic differentiation. Indeed, individuals located at the two extremes of the species' intertidal range are potentially exchanging genes (ca. $100 \mathrm{~m}$ apart) and are exposed to very different environmental conditions. The same design was replicated in the two Northern sites: Audresselles and Gris$\mathrm{Nez}$ (two data sets).

The third set involved crosses between the two Northern sites to test if reproductive isolation can occur between populations separated by a distance of less than $5 \mathrm{~km}$.

The fourth set of crosses was designed to test compatibility between individuals from different geographical origins $(1,000 \mathrm{~km}$ apart) that are assumed to be reproductively isolated. These crosses were performed at a later date.

Statistical analyses - All analyses were performed using the SAS statistical package (SAS Institute, Inc., 1988). Two variables were considered: 1) the total number of fertilizations (cystocarps) per centimeter of female thallus, as an estimate of prezygotic isolation; and 2) the percentage of aborted fertilizations (i.e., when the zygote did not develop normally giving a pseudocystocarp), as an estimate of the first stage of postzygotic isolation (number of empty cystocarps per total number of cystocarps).

These two variables were rank transformed into normal scores (proc RANK; SAS, 1988; midranks are used for tied values) in order to make the ANOVA computation a nonparametric test (Sokal and Rohlf, 1981, p. 429). Values reported in the text and tables are untransformed.

Parental identities and population origin effects-A mixed model ANOVA (partially nested for some sets of crosses) was applied as a general design for each set of crosses using the SAS GLM procedure. Type III sums of squares were used for tests of significance (Freund, Littell, and Spector, 1986).

To test effects of parental identities and population origin, the following analyses were performed: 1) The two data sets (Al and $\mathrm{Gl}$ populations) from the first set of crosses were analyzed separately for the effects of both parental identities and the interaction between male and female identity. 2) The two data sets (A and $G$ sites) from the second set of crosses were analyzed separately for the effects of the tidal levels of male and female, the male $\times$ female tidal levels interaction, and both male and female identities nested within tidal levels. Then these two data sets were analyzed together to test the differences between the two sites, and the site $\times$ parental tidal levels interactions. 3) In the third set of crosses, the tested effects were site origins of male and female, the male $\times$ female site interaction, and male and female identities nested within parental site of origin. 4) A similar design to 3) was carried out for the fourth set of crosses, with geographical region instead of site as factor. Male and female tidal level, site, and geographical region are fixed effects, and male and female identities are random effects.
Effects of parental proximity-The relationship between interparent distance and reproductive success was assessed in two ways.

At a large scale (between sites), the effect of parental proximity was investigated with a one-way ANOVA, using a pooled data set from northern France populations (crosses of sets 1, 2, and 3), to test differences of reproductive success for within- compared to between-site crosses. The fourth data set was not included because it concerns crosses performed later in the season that gave significantly lower outputs.

At a smaller scale (within sites), the occurrence of a relationship between interparent distance and reproductive success was tested within and among populations (crosses of sets 1 and 2, in which precise distance between male and female was known from the mapping of individuals) using linear and quadratic regressions. The hypothesis of monotonous decrease in reproductive success with increasing distance between mates was tested by a linear regression, while the search for an intermediate optimal outcrossing distance was carried out using a quadratic regression (Mitchell-Olds and Shaw, 1987). As the data used for regression are not independent, because the same individual is used in different crosses, the level of significance of the regression coefficients was assessed using a randomization test (Sokal and Rohlf, 1981, p. 787). This nonparametric method allows one to empirically find the probability of obtaining an equal or higher coefficient than the observed one, with the same set of data in which the variates are randomly rearranged (10,000 random permutations were performed). Nontransformed variates were used for this analysis.

\section{RESULTS}

For the three sets of crosses performed in June, all the females stayed alive and grew during the experiment. The mean number of fertilizations obtained per centimeter of female thallus was $0.42(\mathrm{SE}=0.02, N=269)$. The female thalli grew from $20 \mathrm{~cm}$ at the beginning of the experiment up to a mean thallus length per female individual of 53.9 $\mathrm{cm}(\mathrm{SE}=0.9, N=269)$. Among the 269 crosses performed, only 15 gave no cystocarps at all $(6 \%)$ and thus were removed from the analysis for abortion rate. Among the 5,744 cystocarps initiated, 2,325 failed to give spores, leading to $40.5 \%$ abortion on average.

For the fourth set of crosses performed in September, over the 81 crosses, only 62 female thalli stayed alive throughout the experiment, so that mortality rate was high (23.4\%) compared to the June experiment. The mean number of fertilizations obtained per centimeter of female thallus was $0.12(\mathrm{SE}=0.03, N=62)$ and mean length of female was $8.2 \mathrm{~cm}(\mathrm{SE}=1.4, N=62)$, due to thallus decay. More than half of the crosses $(59.7 \%)$ gave no cystocarps at all and thus were removed from the analysis for abortion rate. Of the 104 cystocarps initiated, 32 failed to give spores, leading to $30.8 \%$ abortion on average.

Parental identity effects-Male effect-No male identity effect is demonstrated in this study. There is no significant variability between males belonging to the same population for mean reproductive success, fertility and 
TABLE 1. Mean number of fertilizations per centimeter of thallus and mean abortion percentage for each crossing combination within populations (first set of crosses).

\begin{tabular}{|c|c|c|c|c|c|c|c|c|c|c|c|c|}
\hline \multicolumn{13}{|c|}{ a) In Audresselles low tidal level population (Al) } \\
\hline \multirow[b]{2}{*}{ Females } & \multicolumn{5}{|c|}{ Males } & \multirow{2}{*}{$\begin{array}{c}\text { Female } \\
\text { mean }\end{array}$} & \multicolumn{5}{|c|}{ Males } & \multirow{2}{*}{$\underset{\text { mean }}{\text { Female }}$} \\
\hline & 1 & 2 & 3 & 4 & 5 & & 1 & 2 & 3 & 4 & 5 & \\
\hline 1 & 0.26 & 0.80 & 0.28 & 0.34 & 0.51 & 0.44 & 39.40 & 38.70 & 50.00 & 62.50 & 45.80 & 47.30 \\
\hline 2 & 0.46 & 0.39 & 0.32 & 0.22 & 0.38 & 0.36 & 40.40 & 27.40 & 31.70 & 72.70 & 23.10 & 39.10 \\
\hline 3 & 0.41 & 0.74 & 0.90 & 0.68 & 0.93 & 0.73 & 67.80 & 23.90 & 13.20 & 44.00 & 4.60 & 30.70 \\
\hline 4 & 0.56 & 0.62 & 0.50 & 0.81 & 0.07 & 0.51 & 65.60 & 64.90 & 78.90 & 34.40 & 60.70 & 60.90 \\
\hline 5 & 0.60 & 0.43 & 0.55 & 0.48 & 0.16 & 0.44 & 46.40 & 39.20 & 38.00 & 46.00 & 83.30 & 47.00 \\
\hline Male mean & 0.46 & 0.60 & 0.51 & 0.51 & 0.41 & & 51.90 & 38.80 & 42.40 & 51.90 & 39.10 & \\
\hline
\end{tabular}

b) In Gris Nez low tidal level population (G1)

\begin{tabular}{|c|c|c|c|c|c|c|c|c|c|c|c|c|c|c|}
\hline \multirow[b]{3}{*}{ Females } & \multicolumn{7}{|c|}{ Fertility } & \multicolumn{7}{|c|}{ Abortion } \\
\hline & \multicolumn{6}{|c|}{ Males } & \multirow{2}{*}{$\begin{array}{c}\text { Female } \\
\text { mean }\end{array}$} & \multicolumn{6}{|c|}{ Males } & \multirow{2}{*}{$\begin{array}{c}\text { Female } \\
\text { mean }\end{array}$} \\
\hline & 1 & 2 & 3 & 4 & 5 & 6 & & 1 & 2 & 3 & 4 & 5 & 6 & \\
\hline 1 & 0.76 & 0.85 & 1.18 & 1.09 & 0.97 & 1.32 & 1.03 & 25.40 & 35.90 & 37.30 & 55.10 & 45.00 & 29.10 & 38.00 \\
\hline 2 & 0.14 & 0.34 & 0.29 & 0.30 & 0.21 & 0.16 & 0.24 & 55.60 & 63.90 & 65.00 & 91.00 & 56.60 & 61.90 & 66.30 \\
\hline 3 & 0.14 & 0.21 & 0.16 & 0.07 & 0.42 & 0.28 & 0.21 & 36.70 & 32.90 & 9.50 & 16.70 & 32.50 & 50.90 & 29.90 \\
\hline 4 & 0.07 & 0.12 & 0.14 & 0.16 & 0.40 & 0.29 & 0.20 & 39.30 & 55.30 & 39.60 & 46.40 & 20.50 & 41.00 & 40.40 \\
\hline 5 & 0.23 & 0.12 & 0.33 & 0.09 & 0.11 & 0.10 & 0.16 & 77.30 & 100.00 & 80.60 & 75.00 & 82.90 & 90.00 & 84.70 \\
\hline 6 & 0.00 & 0.05 & 0.01 & 0.20 & 0.06 & 0.17 & 0.08 & - & 100.00 & 100.00 & 80.40 & 75.00 & 78.80 & 84.80 \\
\hline Male mean & 0.23 & 0.30 & 0.37 & 0.34 & 0.37 & 0.41 & & 44.20 & 60.60 & 51.70 & 59.80 & 52.10 & 55.60 & \\
\hline
\end{tabular}

abortion rate (within the two populations $\mathrm{Al}$ and $\mathrm{Gl}$, first set of crosses: Table 1 for means, Table 2 for ANOVA results). This result is confirmed by the absence of male identity effect in the other sets of crosses. Indeed, male effect is not significant when nested 1) within tidal level origin of males (Table 3 ), 2) within site origin of males, where its higher signification level is obtained $(P=0.092$,

TABLE 2. ANOVA on number of fertilizations per centimeter of thallus and percentage of abortion within-population crosses in population A1 and G1 (first set of crosses, rank tranformed data, using type III sums of squares).

\begin{tabular}{lrrrr}
\hline \hline \multicolumn{1}{c}{ Source of variation } & \multicolumn{1}{c}{ df } & \multicolumn{1}{c}{ MS } & \multicolumn{1}{c}{$F$} & $P$ \\
\multicolumn{4}{c}{ a) Number of fertilizations } \\
Population A1 $(N=50)$ & & & & \\
Male identity & 4 & 1,463 & 1.07 & 0.403 \\
Female identity & 4 & 1,300 & 0.95 & 0.460 \\
Male $\times$ female interaction & 16 & 1,366 & 1.37 & 0.234 \\
Error & 25 & 998 & & \\
Population G1 $(N=96)$ & & & & \\
Male identity & 5 & 1,010 & 1.27 & 0.308 \\
Female identity & 5 & 23,410 & 29.43 & $<0.001^{* * *}$ \\
Male $\times$ female interaction & 25 & 795 & 1.44 & 0.127 \\
Error & 60 & 553 & & \\
& & & & \\
& b) Abortion rate & & \\
Population A1 $(N=50)$ & & & & \\
Male identity & 4 & 468 & 0.33 & 0.857 \\
Female identity & 4 & 3,326 & 2.32 & 0.101 \\
Male $\times$ female interaction & 16 & 1,431 & 1.31 & 0.264 \\
Error & 24 & 1,091 & & \\
Population G1 $(N=96)$ & & & & \\
Male identity & 5 & 707 & 0.94 & 0.474 \\
Female identity & 5 & 15,118 & 20.05 & $<0.001^{* * *}$ \\
Male $\times$ female interaction & 24 & 754 & 0.90 & 0.599 \\
Error & 53 & 837 & & \\
\hline
\end{tabular}

Table 4), and 3) within geographical origin of males (Table $5)$.

Female effect-Variability among females for reproductive success is revealed at all tested scales. It is slightly stronger on abortion rate than on fertility, and depends on the site of origin of the females.

In within-population crosses, the range of variation among female means is always wider than that of males (Table 1). Variation among females depends on the population, and is larger in the Gl population (Table 1: mean female fertility ranged from 0.08 to 1.03 in Gl, from 0.36 to 0.73 in $\mathrm{Al}$; mean female abortion rate ranged from 29.9 to 84.8 in $\mathrm{Gl}$, and from 30.7 to 60.9 in $\mathrm{Al}$ ). The female effect is thus highly significant within Gl, but not within $\mathrm{Al}$ (Table 2), for both fertility and abortion.

In larger scale crosses, there is a female effect on abortion rate when nested 1) within tidal level origin of female in both sites Audresselles and Gris-Nez (Table 3b), and 2) within site origin of female $(P=0.067$, Table $4 b)$. It could not be tested in the fourth set of crosses between mates from different geographical origins (Table 5) because of the low fertilization rate in this experiment.

Female effect on number of fertilizations, nested within female tidal level, is significant in the Gris-Nez site (Table $3 a)$, but only close to significant $(P=0.071$, Table $3 a)$ in the Audresselles site. As a result, female effect nested within site is not significant over northern populations (Table 4a). Nevertheless, fertility varies significantly among females in the fourth set of crosses between mates from different geographical origins (Table 5).

Male $\times$ female interaction - The lack of significance of the male $\times$ female interaction suggests that female reproductive success does not depend on the male donor (Table 1 for means; Table 2 for ANOVA results). 
TABLE 3. ANOVA on number of fertilizations per centimeter of thallus and percentage of abortion for crosses between tidal levels within sites Audresselles and Gris-Nez (second set of crosses, rank transformed data, using type III sums of squares).

\begin{tabular}{|c|c|c|c|c|}
\hline Source of variation & df & MS & $F$ & $P$ \\
\hline \multicolumn{5}{|c|}{ a) Number of fertilizations } \\
\hline \multicolumn{5}{|l|}{ Site Audresselles $(N=48)$} \\
\hline $\begin{array}{l}\text { Male tidal level } \\
\text { Female tidal level } \\
\text { Male tidal level } \times \text { female tidal level } \\
\text { Male identity within male tidal level } \\
\text { Female identity within female tidal level } \\
\text { Error }\end{array}$ & $\begin{array}{r}1 \\
1 \\
1 \\
14 \\
10 \\
20\end{array}$ & $\begin{array}{r}3,163 \\
497 \\
1 \\
676 \\
848 \\
396\end{array}$ & $\begin{array}{l}4.67 \\
0.59 \\
0.00 \\
1.71 \\
2.14\end{array}$ & $\begin{array}{l}0.048^{*} \\
0.461 \\
0.973 \\
0.138 \\
0.071\end{array}$ \\
\hline \multicolumn{5}{|l|}{ Site Gris-Nez $(N=56)$} \\
\hline $\begin{array}{l}\text { Male tidal level } \\
\text { Female tidal level } \\
\text { Male tidal level } \times \text { female tidal level } \\
\text { Male identity within male tidal level } \\
\text { Female identity within female tidal level } \\
\text { Error }\end{array}$ & $\begin{array}{r}1 \\
1 \\
1 \\
14 \\
12 \\
26\end{array}$ & $\begin{array}{r}11 \\
816 \\
30 \\
284 \\
2,264 \\
233\end{array}$ & $\begin{array}{l}0.04 \\
0.36 \\
0.13 \\
1.22 \\
9.72\end{array}$ & $\begin{array}{l}0.846 \\
0.559 \\
0.723 \\
0.319 \\
<0.001^{* * *}\end{array}$ \\
\hline \multicolumn{5}{|l|}{ Data pooled over the two sites $(N=104)$} \\
\hline $\begin{array}{l}\text { Site } \\
\text { Site } \times \text { male tidal level } \\
\text { Site } \times \text { female tidal level } \\
\text { Error }\end{array}$ & $\begin{array}{r}1 \\
1 \\
1 \\
100\end{array}$ & $\begin{array}{r}5,098 \\
1,958 \\
95 \\
868\end{array}$ & $\begin{array}{l}5.87 \\
2.26 \\
0.11\end{array}$ & $\begin{array}{l}0.017^{*} \\
0.136 \\
0.744\end{array}$ \\
\hline \multicolumn{5}{|c|}{ b) Abortion rate } \\
\hline \multicolumn{5}{|l|}{ Site Audresselles $(N=45)$} \\
\hline $\begin{array}{l}\text { Male tidal level } \\
\text { Female tidal level } \\
\text { Male tidal level } \times \text { female tidal level } \\
\text { Male identity within male tidal level } \\
\text { Female identity within female tidal level } \\
\text { Error }\end{array}$ & $\begin{array}{r}1 \\
1 \\
1 \\
14 \\
10 \\
17\end{array}$ & $\begin{array}{r}91 \\
1,133 \\
64 \\
408 \\
1,014 \\
308\end{array}$ & $\begin{array}{l}0.22 \\
1.12 \\
0.21 \\
1.32 \\
3.29\end{array}$ & $\begin{array}{l}0.644 \\
0.315 \\
0.653 \\
0.289 \\
0.015^{*}\end{array}$ \\
\hline \multicolumn{5}{|l|}{ Site Gris-Nez $(N=55)$} \\
\hline $\begin{array}{l}\text { Male tidal level } \\
\text { Female tidal level } \\
\text { Male tidal level } \times \text { female tidal level } \\
\text { Male identity within male tidal level } \\
\text { Female identity within female tidal level } \\
\text { Error }\end{array}$ & $\begin{array}{r}1 \\
1 \\
1 \\
14 \\
12 \\
25\end{array}$ & $\begin{array}{r}136 \\
9,818 \\
292 \\
275 \\
1,802 \\
251\end{array}$ & $\begin{array}{l}0.50 \\
5.45 \\
1.16 \\
1.10 \\
7.17\end{array}$ & $\begin{array}{l}0.492 \\
0.037^{*} \\
0.291 \\
0.406 \\
<0.001^{* * *}\end{array}$ \\
\hline \multicolumn{5}{|l|}{ Data pooled over the two sites $(N=100)$} \\
\hline $\begin{array}{l}\text { Site } \\
\text { Site } \times \text { male tidal level } \\
\text { Site } \times \text { female tidal level } \\
\text { Error }\end{array}$ & $\begin{array}{r}1 \\
1 \\
1 \\
96\end{array}$ & $\begin{array}{r}4,327 \\
19 \\
9,859 \\
786\end{array}$ & $\begin{array}{r}5.50 \\
0.02 \\
12.54\end{array}$ & $\begin{array}{l}0.021^{*} \\
0.889 \\
<0.001^{* * *}\end{array}$ \\
\hline
\end{tabular}

Population origin effects - Effects of male and female tidal level origins - Means for males or females coming from high or low tidal levels are given in the two sites in Fig. 1. Effects of the tidal level on reproductive success of males or females are not generally evident (Table 3 ). Only two results are significant. 1) In the Audresselles site, males coming from the higher tidal level are signif-. icantly more fertile than those from the lower level. Mean values for females show the same trend, although not significant. 2) In the Gris-Nez site, females coming from the higher tidal level population abort significantly less than those coming from the lower level. The opposite is observed in the Audresselles site (Fig. 1), as indicated by the highly significant interaction between site and female tidal level for abortion rate $(P<0.001$; Table $3 b$, data pooled over the two sites).
There is no significant interaction between the tidal level of the male and the tidal level of the female, for either variable, and at either site (Table 3).

Effects of male and female site of origin-There is no significant effect of either male or female site of origin on either the number of fertilizations or the abortion rate (Table 4 for ANOVA results and Table 6 for means). Nevertheless, females from Audresselles tend to be more fertile than females from Gris-Nez (fertility of females coming from Audresselles was 0.61 compared to 0.36 for Gris-Nez females, Table 6; $P=0.087$; Table 4a). The higher fertility of Audresselles females leads to a higher reproductive output of within Audresselles matings compared to within Gris-Nez matings (Table 6). 
TABLE 4. ANOVA on number of fertilizations per centimeter of thallus and percentage of abortion for crosses between sites Audresselles and Gris-Nez (third set of crosses, rank transformed data, using type III sums of squares).

\begin{tabular}{|c|c|c|c|c|}
\hline Source of variation & df & MS & $F$ & $P$ \\
\hline \multicolumn{5}{|c|}{ a) Number of fertilizations } \\
\hline Male site origin & 1 & 169 & 1.82 & 0.197 \\
\hline Female site origin & 1 & 566 & 3.35 & 0.087 \\
\hline Male site origin $\times$ female site & 1 & 130 & 4 & 0.169 \\
\hline Male identity within (male site origin) & 15 & 93 & 3.17 & 0.265 \\
\hline $\begin{array}{l}\text { Female identity within (female site } \\
\text { origin) }\end{array}$ & 15 & 169 & 5.75 & 0.158 \\
\hline Error & 2 & 29 & & \\
\hline \multicolumn{5}{|c|}{ b) Abortion rate } \\
\hline Male & 1 & 147 & 1.82 & 0.198 \\
\hline Female site origin & 1 & 117 & 0.77 & 0.395 \\
\hline Male identity within (male site origi & 15 & 81 & 72.23 & 0.092 \\
\hline $\begin{array}{l}\text { Female identity within (female site } \\
\text { origin) }\end{array}$ & 15 & 153 & 136.30 & 0.067 \\
\hline Error & 1 & 1 & & \\
\hline
\end{tabular}

This difference in reproductive output between sites is confirmed by analysis of the data from the second set of crosses (Fig. 1; significant site effect for fertility, Table 3a; and for abortion rate, Table $3 \mathrm{~b}$; data pooled over the two sites).

There is no significant interaction between the site of the female and the site of the male for fertility (Table 4a). Interaction could not be tested for abortion due to missing values (sterile crosses).

Effects of male and female geographical origin-Roscoff females had a significantly lower fertility than those coming from the other regions (Table 5 for results of ANOVA, Table 7 for means). Interaction between male and female origin was significant $(P=0.006$; Table 5$)$. However, it does not indicate a systematically greater success of crosses involving mates coming from the same geographical origin, because Bouzigues females are more fertile when mated with males from Roscoff than with males from their own locality (Table 7).

Abortion rate has not been statistically analyzed because this set of crosses performed later in the season had a high rate of mortality and sterility; the means are given in Table 7, and do not show clear differences between within- and between-region crosses.

Effect of parental proximity - At a large scale-Fertility does not vary significantly for within- and between-site

TABLE 5. ANOVA on number of fertilizations per centimeter of thallus for crosses between geographical origins: northern France, Roscoff, and Bouzigues (fourth set of crosses, rank transformed data, using type III sums of squares).

\begin{tabular}{lrrrl}
\hline \hline \multicolumn{1}{c}{ Source of variation } & df & MS & \multicolumn{1}{c}{$F$} & \multicolumn{1}{c}{$P$} \\
\hline Male geographical origin & 2 & 21 & 0.12 & 0.900 \\
Female geographical origin & 2 & 2,405 & 5.53 & $0.043^{*}$ \\
Male origin $\times$ female origin & 4 & 579 & 4.26 & $0.006^{* *}$ \\
Male identity (within male origin) & 6 & 178 & 1.31 & 0.277 \\
Female identity (within female & & & & \\
$\quad \begin{array}{l}\text { origin) } \\
\text { Error }\end{array}$ & 6 & 435 & 3.20 & $0.012^{*}$ \\
\hline
\end{tabular}
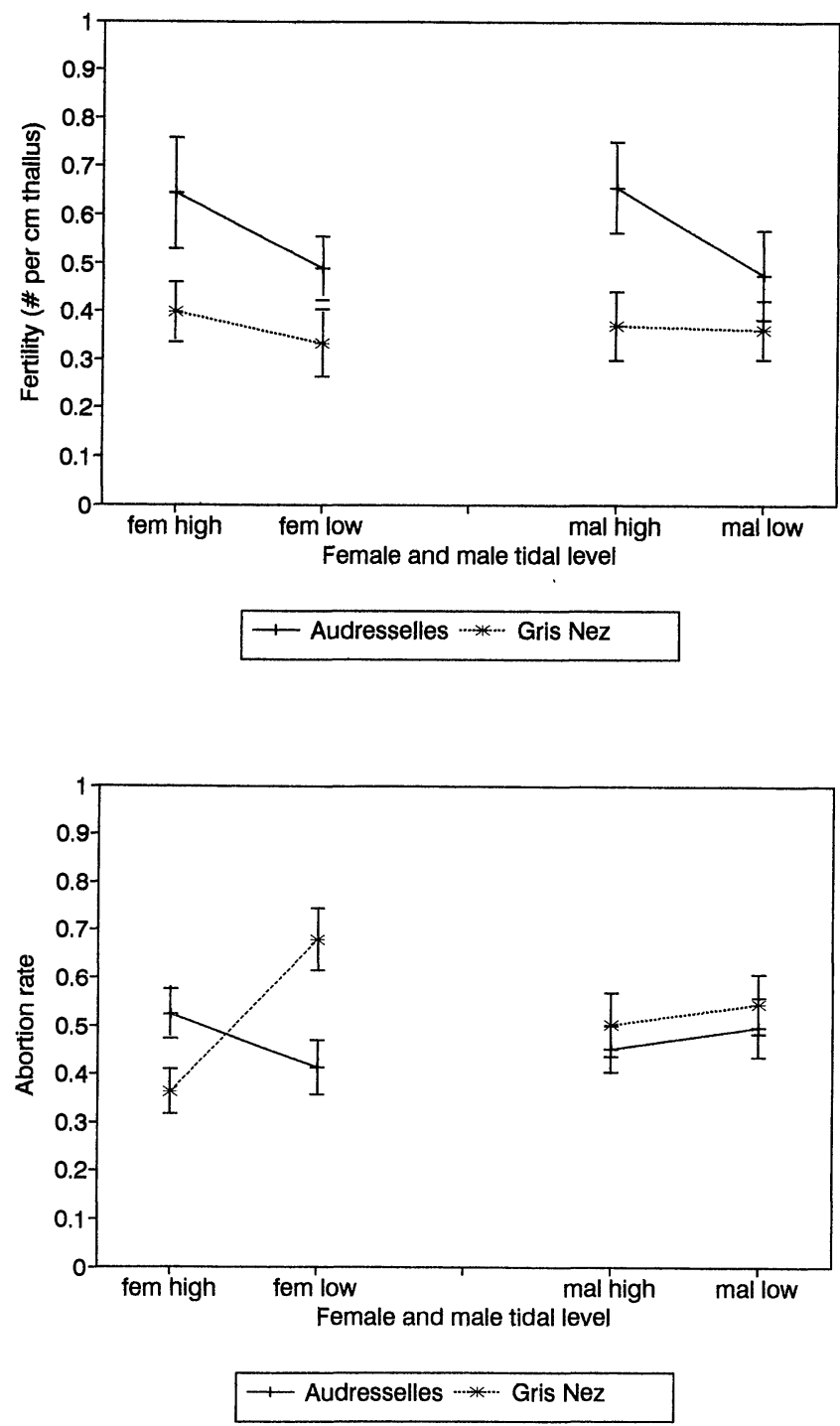

Fig. 1. Effect of the tidal level of the mates on crossing success. Mean number of fertilizations per centimeter female thallus and mean percentage of abortion are shown for crosses between tidal levels high and low, within sites Audresselles and Gris-Nez (second set of crosses). Standard error of the mean is indicated. $\mathrm{fem}=$ females, $\mathrm{mal}=$ males.

crosses (Table 8a; Fig. 2), while a nearly significant decrease in abortion rate is observed for between-site crosses $(P=0.068$; Table 8b; Fig. 2).

At a smaller scale-No significant effect of interparent distance is found on the two components of reproductive success, within distances less than $20 \mathrm{~m}$, that correspond to within-population crosses (Table 9a for regression analyses and Fig. 3).

Nevertheless, when between-population crosses are included, a significant quadratic effect of distance on fertility is revealed (Table 9b; Fig. 4). The slope of the distance term is negative and the quadratic term (squared distance) is positive, which suggests that the number of fertilizations does not increase linearly with crossing distance. Fertility increases from a distance corresponding to between population crosses. 
TABLE 6. Mean number of fertilizations per centimeter of thallus ( \pm standard error) and mean abortion rate ( \pm standard error) for crosses between sites (third set of crosses).

\begin{tabular}{|c|c|c|c|c|}
\hline & \multicolumn{2}{|r|}{ Fertility } & \multicolumn{2}{|c|}{ Abortion rate } \\
\hline & $N$ & Mean \pm SE & $N$ & Mean \pm SE \\
\hline \multicolumn{5}{|l|}{ Male origin effect: } \\
\hline $\begin{array}{l}\text { Male Audresselles (A) } \\
\text { Male Gris Nez (G) }\end{array}$ & $\begin{array}{l}19 \\
20\end{array}$ & $\begin{array}{l}0.44 \pm 0.10 \\
0.54 \pm 0.11\end{array}$ & $\begin{array}{l}19 \\
18\end{array}$ & $\begin{array}{l}0.48 \pm 0.07 \\
0.41 \pm 0.08\end{array}$ \\
\hline \multicolumn{5}{|l|}{ Female origin effect: } \\
\hline $\begin{array}{l}\text { Female A } \\
\text { Female G }\end{array}$ & $\begin{array}{l}20 \\
19\end{array}$ & $\begin{array}{l}0.61 \pm 0.12 \\
0.36 \pm 0.08\end{array}$ & $\begin{array}{l}18 \\
19\end{array}$ & $\begin{array}{l}0.40 \pm 0.06 \\
0.49 \pm 0.08\end{array}$ \\
\hline \multicolumn{5}{|l|}{ Within site crosses: } \\
\hline $\begin{array}{l}\text { Audresselles site } \\
\text { Gris Nez site }\end{array}$ & $\begin{array}{l}10 \\
10\end{array}$ & $\begin{array}{l}0.56 \pm 0.17 \\
0.41 \pm 0.14\end{array}$ & $\begin{array}{r}10 \\
1\end{array}$ & $\begin{array}{l}0.48 \pm 0.09 \\
0.50 \pm 0.13\end{array}$ \\
\hline \multicolumn{5}{|l|}{ Between sites crosses: } \\
\hline $\begin{array}{l}\text { Male } G \times \text { female } A \\
\text { Male } A \times \text { female } G\end{array}$ & $\begin{array}{r}10 \\
9\end{array}$ & $\begin{array}{l}0.66 \pm 0.17 \\
0.31 \pm 0.07\end{array}$ & $\begin{array}{l}8 \\
9\end{array}$ & $\begin{array}{l}0.30 \pm 0.09 \\
0.48 \pm 0.12\end{array}$ \\
\hline
\end{tabular}

For abortion rates the same trend is revealed, close to significance (Table 9b; Fig. 4).

\section{DISCUSSION}

This study demonstrates that the major source of variation of early components of crossing success is the female identity effect. Second, it shows that crossing success is also significantly influenced by mate origin and especially that of the female parent. Finally, an effect of interparent distance is observed on fertility.

Parental identity effects and sexual selection in a red alga-Variation among females is a major cause of differential crossing success in Gracilaria verrucosa. Indeed, female identity effect on prezygotic and/or postzygotic control was found whatever the geographical scale of the crosses (within-population, Table 2; between close populations, Table 3; between sites, Table 4, between regions, Table 5). This indicates that there is phenotypic variability among females for reproductive success, either genetic or due to an epigenetic maternal effect. An effect of female identity on reproductive success is expected when fertilization occurs on the female. In higher plants, extensive

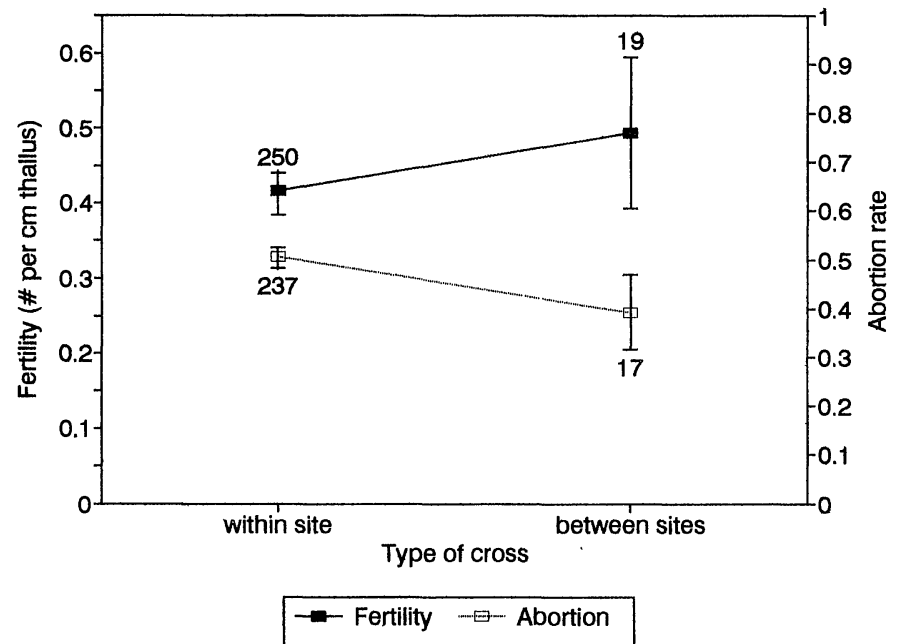

Fig. 2. Effect of parental proximity on crossing success at a large scale. Mean number of fertilizations per centimeter female thallus and mean rate of abortion are shown for crosses within and between the two northern sites, Audresselles and Gris-Nez, distant from $5 \mathrm{~km}$ (pooled crosses of sets 1,2, and 3). Standard error of the means and number of observations are indicated.

evidence documents the effects of the female parent on pollen germination, abortion rate, seed set, and offspring fitness (Hill and Lord, 1986; Marshall and Ellstrand, 1986, 1988; Mazer, 1987; Roach and Wulff, 1987; Fenster and Sork, 1988; Hossaert and Valero, 1988; Pittman and Levin, 1989; Schlichting and Devlin, 1989; Fenster, 1991a). Here we demonstrate for the first time that the same phenomenon exists in an oogamous alga. In this species, fertilization occurs on the female gametophyte, and the reproductive success seems to be dependent on the processing and transfer of photoassimilate from the female to the zygote development (cystocarp) (Hommersand and Fredericq, 1990). This functional relationship between the cystocarp and the female gametophyte may account for the strong maternal effect revealed in this study (this point is further discussed in the last paragraph of the discussion).

The absence of variation among males for reproductive success suggests that the quantity and quality of the male

TABLE 7. Means and standard errors for crosses between localities (fourth set of crosses).

\begin{tabular}{|c|c|c|c|c|c|c|c|c|c|}
\hline \multirow[b]{3}{*}{$\begin{array}{l}\text { Female } \\
\text { locality }\end{array}$} & & \multicolumn{4}{|c|}{ Fertility } & \multicolumn{4}{|c|}{ Abortion } \\
\hline & & \multicolumn{3}{|c|}{ Male locality } & \multirow[b]{2}{*}{$\begin{array}{c}\text { Female } \\
\text { mean }\end{array}$} & \multicolumn{3}{|c|}{ Males } & \multirow[b]{2}{*}{$\begin{array}{c}\text { Female } \\
\text { mean }\end{array}$} \\
\hline & & $\begin{array}{c}\text { Northern } \\
\text { France }\end{array}$ & Roscoff & Bouzigues & & $\begin{array}{c}\begin{array}{c}\text { Northern } \\
\text { France }\end{array} \\
\end{array}$ & Roscoff & Bouzigues & \\
\hline Northern France & $\begin{array}{l}N \\
\text { Mean } \\
\text { SE }\end{array}$ & $\begin{array}{c}7 \\
0.326 \\
0.145\end{array}$ & $\begin{array}{c}9 \\
0.085 \\
0.035\end{array}$ & $\begin{array}{c}5 \\
0.258 \\
0.143\end{array}$ & $\begin{array}{l}0.207 \\
0.062\end{array}$ & $\begin{array}{c}7 \\
0.584 \\
0.179\end{array}$ & $\begin{array}{c}4 \\
0.250 \\
0.083\end{array}$ & $\begin{array}{c}4 \\
0.299 \\
0.140\end{array}$ & $\begin{array}{l}0.419 \\
0.098\end{array}$ \\
\hline Roscoff & $\begin{array}{l}N \\
\text { Mean } \\
\text { SE }\end{array}$ & $\begin{array}{c}8 \\
0.003 \\
0.003\end{array}$ & $\begin{array}{c}9 \\
0.028 \\
0.028\end{array}$ & $\begin{array}{c}5 \\
0.000 \\
0.000\end{array}$ & $\begin{array}{l}0.013 \\
0.011\end{array}$ & $\begin{array}{c}1 \\
1.000 \\
-\end{array}$ & $\begin{array}{c}1 \\
1.000 \\
-\end{array}$ & $\begin{array}{l}0 \\
-\end{array}$ & $\begin{array}{c}1.000 \\
-\end{array}$ \\
\hline Bouzigues & $\begin{array}{l}N \\
\text { Mean } \\
\text { SE }\end{array}$ & $\begin{array}{c}7 \\
0.075 \\
0.075\end{array}$ & $\begin{array}{c}9 \\
0.243 \\
0.131\end{array}$ & $\begin{array}{c}3 \\
0.086 \\
0.086\end{array}$ & $\begin{array}{l}0.156 \\
0.069\end{array}$ & $\begin{array}{c}1 \\
0.000 \\
-\end{array}$ & $\begin{array}{c}6 \\
0.222 \\
0.102\end{array}$ & $\begin{array}{c}1 \\
0.200 \\
-\end{array}$ & $\begin{array}{l}0.191 \\
0.080\end{array}$ \\
\hline Male mean & $\begin{array}{l}\text { Mean } \\
\text { SE }\end{array}$ & $\begin{array}{l}0.129 \\
0.058\end{array}$ & $\begin{array}{l}0.119 \\
0.048\end{array}$ & $\begin{array}{l}0.119 \\
0.063\end{array}$ & & $\begin{array}{l}0.565 \\
0.160\end{array}$ & $\begin{array}{l}0.303 \\
0.092\end{array}$ & $\begin{array}{l}0.279 \\
0.110\end{array}$ & \\
\hline
\end{tabular}


3
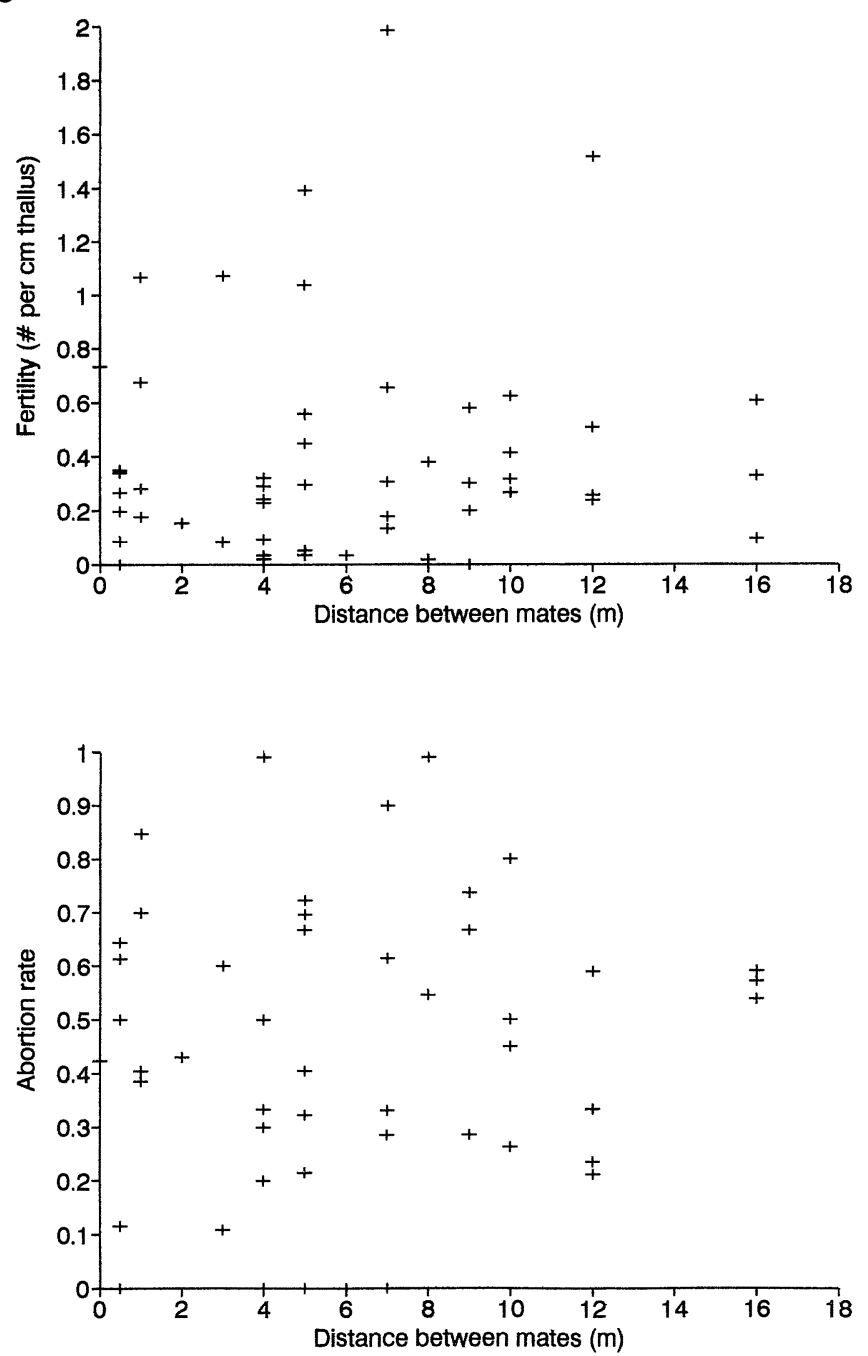

4
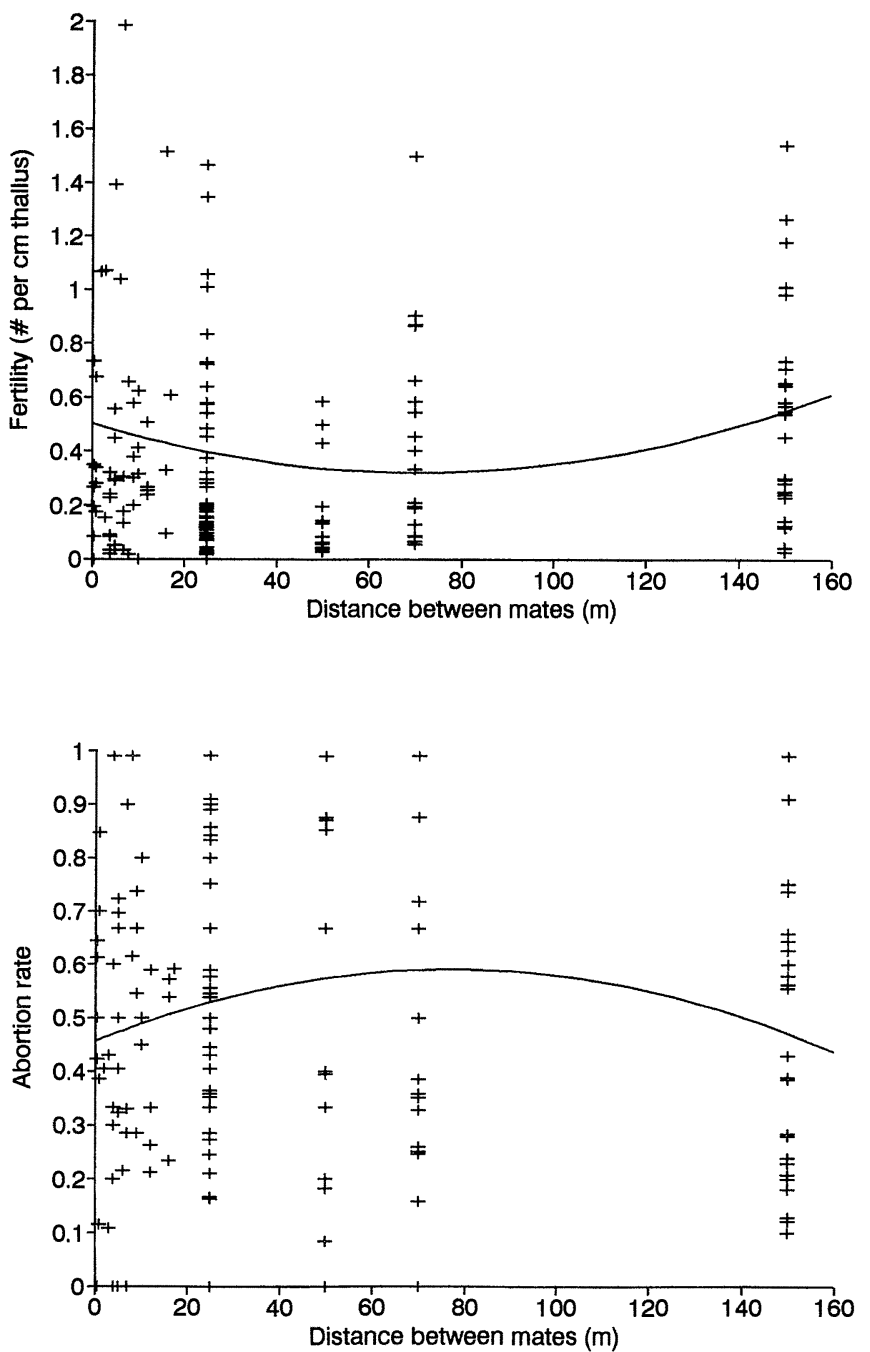

Figs. 3, 4. Effect of parental proximity on crossing success at a smaller scale, within the two northern sites, Audresselles and Gris-Nez. The number of fertilizations per centimeter female thallus and the rate of abortion for each cross are plotted against distance between mates. 3. Withinpopulation crosses. 4. Within-site crosses. Quadratic regressions lines are drawn-in straight line when significant and dotted line when close to significance level-and correspond to the following equations: fertility $=0.50140-0.00514 \cdot$ distance $+0.00004 \cdot(\text { distance })^{2}, P($ linear term $)=$ $0.007 ; P($ quadratic term $)=0.002 ;$ abortion $=0.45521+0.00349 \cdot$ distance $-0.0002 \cdot(\text { distance })^{2}, P($ linear term $)=0.051 ; P($ quadratic term $)=0.069$.

gametes emitted do not differ among males, and that male competition should be low. In higher plants, male effects are difficult to demonstrate, and may depend on experimental conditions (Fenster and Sork, 1988; Marshall, 1988, 1991; Marshall and Whittaker, 1989; Schlichting and Devlin, 1989; Cruzan, 1990; Fenster, 1991a).

No variation for crossing success could be revealed among male $\times$ female combinations. Male $\times$ female interactions in higher plants cover a variety of complex phenomena, such as complementarity between male and female genomes (Charlesworth, Schemske, and Sork, 1987; Queller, 1987; Lyons et al., 1989; Marshall and Folsom, 1991), and are not easily demonstrated (Hill and Lord, 1986; Marshall, 1988; Schlichting and Devlin, 1989; Nakamura and Wheeler, 1992).

The lack of male identity effect and male $\times$ female interactions in this study suggests that the possibility for sexual selection is reduced in red algae compared to higher plants. In higher plants, $60 \%$ to $80 \%$ of the sporophytic genes are expressed in the pollen tube (Tanksley, Zamir, and Rick, 1981; Sari Gorla et al., 1986), and there is opportunity for sexual selection through gametophytic competition among pollen tubes and pollen-style interactions (Haldane, 1932; Mulcahy, Curtis, and Snow, 1983; Charlesworth, Schemske, and Sork, 1987). The opportunity for sexual selection is different in red algae, first because of the haplo-diploid life cycle, and second because of algal reproductive characteristics. In haplo-diploid species, selection on the gametophytic phase differs from that of higher plants, because the haploid phase is individualized, and may even be isomorphic to the diploid phase (as in G. verrucosa). It is thus submitted to very similar selection forces as the diploid phase, and this prior to gamete production. On the other hand, algal reproductive features seem unlikely to produce any selection-arena as in higher plants (Labeyrie and Rojas-Rousse, 1985; Stearns, 1987). There are few opportunities for competition between male gametes in red algae, because 1) male 
TABLE 8. Effect of parental proximity at a large scale: ANOVA on number of fertilizations per centimeter of thallus and percentage of abortion for within and between-sites crosses $(1,2$, and 3 pooled set of crosses, rank transformed data, using type I sums of squares).

\begin{tabular}{lcccc}
\hline \hline Source of variation & df & MS & $F$ & $P$ \\
\hline \multicolumn{5}{c}{ a) Number of fertilizations } \\
Type of cross & 1 & 2,277 & 0.38 & 0.541 \\
Error & 267 & 6,066 & & \\
& b) Abortion rate & & \\
Type of cross & 1 & 17,977 & 3.37 & 0.068 \\
Error & 252 & 5,334 & & \\
\hline
\end{tabular}

gametes are nonflagellated and nonmotile, and 2) there is no known morphological female structure similar to the style or stigma, where competition among male gametes could occur, since the female carpogonium consists only of a few cells. More than one male nucleus has never been observed around the carpogonium during fertilization (Fredericq and Hommersand, 1989). Thus fertilization is assumed to be a rare event, the outcome of which is maximized through zygote multiplication in the cystocarp (Searles, 1980). As a result, we should expect mate choice through male gamete competition to be difficult to operate, as male gametes might be a factor limiting female fertility. This does not prevent a possible choice of the male gamete by the female that can be demonstrated when the genetic divergence between mates is sufficient, as we will see later.

However, effects of male identity or male $\times$ female interaction could have been missed due to the experimental conditions. Experiments were designed to maximize the number of fertilizations, with a long contact between mates, and involved only single-male crosses. As gametes are produced by mitosis on haploid individuals, all male as well as female gametes are genetically identical within each cross, a condition quite different from that in higher plants. More stringent conditions, leading to competition within and among males, might have yielded different results, as has been found in higher plants (Marshall, 1988, 1991; Lyons et al., 1989; Schlichting and Devlin, 1989; Cruzan, 1990).

Effect of male and female population origins-An effect of population origin of mates is clearly demonstrated by our study. Mean reproductive success differs among populations and sites, mainly because of female origin effects. It can be also noticed that variance among females differs between populations.

These phenotypic effects may be due either to genetic or to epigenetic maternal effects. On one hand, if genetic, this differentiation reveals an isolation due to limited gene flow among populations, and even on a small scale, between populations within a site. On the other hand, environmental conditions differ between tidal levels and sites, which could lead to differential resource availability for the individuals and consequently to phenotypic variation in their fertility. The origin effect is mainly expressed for female individuals because fertilization occurs on them (Roach and Wulff, 1987). However, although significant, this effect is relatively weak compared to female identity effect.

Effect of interparental distance on reproductive success: inbreeding depression, outbreeding depression, and heterosis-Our study shows that the distance between mates influences crossing success. In within-population crosses, reproductive success does not vary with interparent distance, ranging from $0.5 \mathrm{~m}$ to $20 \mathrm{~m}$ (Table 9a; Fig. 3). No inbreeding depression is thus revealed. In between-population crosses, reproductive success tends to increase when the distance between the origin population of male and female increases. This trend is found for both fertility and abortion rate in crosses between populations of different tidal levels at the same site (Table 9; Fig. 4). The same trend is present for between-sites crosses, close to significance for abortion rate (Table 8; Fig. 2). Heterosis on prezygotic and early postzygotic stages is thus revealed among populations within the same geographical origin (distant from $50 \mathrm{~m}$ to $5 \mathrm{~km}$ ).

Inbreeding depression is assumed to be mainly caused by the unmasking of deleterious recessive mutations in homozygotes (Levin, 1984, 1989a, b; Charlesworth and Charlesworth, 1987; Johnston, 1992). Therefore a reduction of inbreeding depression is strongly expected in haplo-diploid species, because deleterious mutations are selected against in the haploid stage (Bernstein et al., 1985). A model considering selection acting on the gametophytic phase in higher plants (Charlesworth and Charlesworth, 1992) shows that inbreeding depression is significantly

TABLE 9. Regression analysis of the effect of parental proximity at small scale on number of fertilizations per centimeter of thallus and abortion; slopes for the effect of distance and square distance. $P$ is the probability of higher coefficients of regression estimated by data randomization test (Sokal and Rohlf, 1981, p. 787).

\begin{tabular}{|c|c|c|c|c|c|}
\hline Trait & $\begin{array}{c}\text { Type of } \\
\text { regression }\end{array}$ & $\begin{array}{l}\begin{array}{l}\text { Slope of } \\
\text { distance }\end{array} \\
\end{array}$ & $P$ & $\begin{array}{l}\text { Slope of } \\
\text { distance }^{2}\end{array}$ & $P$ \\
\hline \multicolumn{6}{|c|}{ a) Within population (interparent distance 0.5 to $20 \mathrm{~m}$ ) } \\
\hline Fertility & $\begin{array}{l}\text { Linear } \\
\text { Quadratic }\end{array}$ & $\begin{array}{r}0.01063 \\
-0.00323\end{array}$ & $\begin{array}{l}0.459 \\
0.253\end{array}$ & $0 . \overline{00090}$ & $0 . \overline{279}$ \\
\hline Abortion rate & $\begin{array}{l}\text { Linear } \\
\text { Quadratic }\end{array}$ & $\begin{array}{l}0.00222 \\
0.00399\end{array}$ & $\begin{array}{l}0.177 \\
0.141\end{array}$ & $-0 . \overline{0} 0011$ & $0 . \overline{259}$ \\
\hline \multicolumn{6}{|c|}{ b) Within site (interparent distance 0.5 to $150 \mathrm{~m}$ ) } \\
\hline Fertility & $\begin{array}{l}\text { Linear } \\
\text { Quadratic }\end{array}$ & $\begin{array}{r}0.00057 \\
-0.00514\end{array}$ & $\begin{array}{l}0.115 \\
0.007^{* *}\end{array}$ & $0 . \overline{0} 0004$ & $0 . \overline{00} 2^{* *}$ \\
\hline Abortion rate & $\begin{array}{l}\text { Linear } \\
\text { Quadratic }\end{array}$ & $\begin{array}{l}0.00007 \\
0.00349\end{array}$ & $\begin{array}{l}0.501 \\
0.051\end{array}$ & $-0 . \overline{0} 0002$ & $0 . \overline{069}$ \\
\hline
\end{tabular}


reduced when more than $60 \%$ of the genes are expressed and submitted to selection in pollen. In haplo-diploid species inbreeding depression should be minimum, because in isomorphic species like Gracilaria, the same genes are likely to be expressed in both phases, and selection in the haploid phase is then equivalent to selection in diploid homozygotes. In accordance with this prediction our study does not show any significant inbreeding depression.

In crosses between widely separated individuals, two contradictory effects can be expected, as soon as divergence between parents is sufficient. 1) An enhanced fitness of hybrids (heterosis) can be caused by the masking of mildly deleterious alleles of both parents by dominance (Levin, 1984, 1989a), even in inbred species (Levin and Clay, 1985), or by overdominance due to possession of different alleles at one locus providing high adaptation to a wider environmental range (Shields, 1982; Fenster, 1991c). 2) The reverse effect, i.e., outbreeding depression, is expected in two cases. When parents have evolved specific adaptation to different environments, the F1 may be disadvantaged in either parental environment (Antonovics, 1968; Price and Waser, 1979; Waser and Price, 1983, 1989; Schemske and Pautler, 1984; Bennett and Grace, 1990): outbreeding depression is caused by rupture of genome-environment interactions. Outbreeding depression can also occur when parental genomes have separately evolved strong interloci epistatic interactions and coadapted allelic combinations, which are broken by recombination in F2 (Shields, 1982; Parker, 1992: "intrinsic genomic outbreeding depression"). This latter case is compatible with the observation of a heterosis in F1, before recombination occurs (Shields, 1982). As our experiment focuses only on early components of reproductive success, involving no recombination, occurrence of such an intrinsic outbreeding depression cannot be tested.

The observation of a heterosis effect on early reproductive success between populations of Gracilaria verrucosa seems to indicate that genetic divergence, and thus partial reproductive isolation, could occur between close populations belonging to different tidal levels in a marine environment. Contrary to the intuition that dispersal in the sea is large, data on recruitment (Santelices, 1990), dispersal potentialities (Destombe et al., 1992), and fertilization distances (Destombe, Godin, and Remy, 1990) show that dispersal is leptokurtic and limited to the order of $100 \mathrm{~m}$. This corresponds to the distance between high and low populations in each site that should then be able to diverge genetically. On the one hand, this divergence would be linked with differential adaptation, since tidal level has important selective effects on algae, but on the other hand, it could lead to fixation of mildly deleterious alleles in populations, producing a heterosis effect in crosses between the populations studied.

In higher plants it is not common to find an effect of distance on early components of reproductive success. Most attempts based on early reproductive success, i.e., pollen and seed characters, fail (Galen, Plowright, and Thomson, 1985; Ritland and Ganders, 1987; Fenster and Sork, 1988; Sobrevila, 1988; Newport, 1989; Redmond, Robbins, and Travis, 1989; Fenster, 1991a). These effects may appear only at later stages, on offspring characters (Fenster, 1991c; McCall, Mitchell-Olds, and Waller, 1991;
Johnston, 1992; Parker, 1992). Few studies are able to detect an influence of interparent distance on fertility (Sobrevila, 1988), and, as far as we know, only the work of Waser and Price demonstrates that the same patterns occur for numerous pre- and postzygotic characters (Price and Waser, 1979; Waser and Price, 1983, 1989, 1991a, b; Waser et al., 1987).

In haplo-diploid algae, due to their complex life cycle, numerous developmental stages are likely to reveal a differential crossing compatibility. These are, besides cystocarp formation and spore formation (Hommersand and Fredericq, 1990): the number of spores produced by a cystocarp, the survival of the diploid F1, its fertility involving the process of meiosis, or the fitness of the haploid F2 after segregation. In Gracilaria verrucosa, late depressive effects on F1 have indeed been observed in crosses between widely separated strains (Rice and Bird, 1990).

The possibility of prezygotic isolation as well as selective abortion in algae is poorly known, but pseudocystocarps may reflect such processes, as discussed by Hommersand and Fredericq (1990). Formation of pseudocystocarps, i.e., pericarps containing no diploid spores, has been reported in previous hybridization studies with Gracilaria verrucosa and other Gracilaria species. They appear in interspecific sterile crosses (McLachlan, van der Meer, and Bird, 1977; Plastino and de Oliveira, 1988), or in intraspecific crosses, where their frequency increases with the age of the male gamete (Destombe et al., 1990). The formation of a pseudocystocarp, i.e., the abortion of a fertilization, is assumed to be under the control of interactions between maternal haploid tissue and sporogenic diploid tissue within the cystocarp (nutrients transfer), and specifically of the fusion cell (Hommersand and Fredericq, 1990). Formed just after karyogamy, this fusion cell contains a mixture of haploid and diploid nuclei, and, according to these authors, "may play a role in rejecting incompatible or disharmonious fertilizations." Its role may thus correspond partly to that of the style of higher plants, allowing a mate choice by the female. However this cell does not seem to be a place or arena for intermale competition, since male gametes are rare. Acceptation or rejection of a male gamete by the female could be based on the genetic complementarity between male and female mates, as has been postulated for pollenstyle interaction in plants. The observation of an effect of intermate distance in Gracilaria verrucosa indicates that such a choice is possible, and effective at very early stages namely fertilization and early zygotic development.

\section{LITERATURE CITED}

Antonovics, J. 1968. Evolution in closely adjacent populations. V. Evolution of self-fertility. Heredity 23: 219-238.

BenNetT, B. D., AND J. B. Grace. 1990. Shade tolerance and its effect on the segregation of two species of Louisiana iris and their hybrids. American Journal of Botany 77: 100-107.

Bernstein, H., H. C. Byerly, F. A. Hopf, AND R. E. Michod. 1985. Genetic damage, mutation, and the evolution of sex. Science 229: $1277-1281$.

Charlesworth, D., and B. Charlesworth. 1987. Inbreeding depression and its evolutionary consequences. Annual Review of Ecology and Systematics 18: 237-268.

, AND -1992 . The effects of selection in the gametophyte stage on mutational load. Evolution 46: 703-720. 
- D. W. SCHEMSKe, AND V. L. Sork. 1987. The evolution of plant reproductive characters: sexual versus natural selection. In $\mathrm{S}$. C. Stearns [ed.], The evolution of sex and its consequences, 317335. Birkhauser-Verlag, Basel.

CruZAN, M. B. 1990. Pollen-pollen and pollen-style interactions during pollen tube growth in Erythronium grandiflorum (Liliaceae). American Journal of Botany 77: 116-122.

Destombe, C., J. Godin, Cl. Lefebvre, O. Dehorter, ANd Ph. Vernet. 1992. Differences in dispersal abilities of haploid and diploid spores of Gracilaria verrucosa (Gracilariales, Rhodophyta). Botanica Marina 35: 93-98.

- - - AND J. M. RemY. 1990. Viability and dissemination of spermatia of Gracilaria verrucosa (Gracilariales, Rhodophyta). Hydrobiologia 204/205: 219-223.

- M. VAlero, Ph. Vernet, AND D. Couvet. 1989. What controls haploid-diploid ratio in the red alga Gracilaria verrucosa? Journal of Evolutionary Biology 2: 67-101.

Ducousso, A., D. Petit, M. Valero, ANd Ph. Vernet. 1990. Genetic variation between and within populations of a perennial grass: $\mathrm{Ar}$ rhenatherum elatius. Heredity 65: 179-188.

Fenster, C. B. 1991a. Effect of male pollen donor and female seed parent on allocation of resources to developing seeds and fruit in Chamaecrista fasciculata (Leguminosae). American Journal of Botany 78: 13-23.

- 1991b. Gene flow in Chamaecrista fasciculata (Leguminosae) I. Gene dispersal. Evolution 45: 398-409.

1991c. Gene flow in Chamaecrista fasciculata (Leguminosae) II. Gene establishment. Evolution 45: 410-422.

- AND V. L. SORK. 1988. Effect of crossing distance and male parent on in vivo pollen tube growth in Chamaecrista fasciculata. American Journal of Botany 75: 1898-1903.

FredericQ, S., AND M. H. Hommersand. 1989. Proposal of the Gracilariales Ord. Nov. (Rhodophyta) based on an analysis of the reproductive development of Gracilaria verrucosa. Journal of Phycology 25: 213-227.

Freund, R. J., R. C. Littell, AND P. C. Spector. 1986. SAS system for linear models. SAS Institute, Inc., Cary, NC.

Galen, C., R. C. Plowright, AND J. D. ThOmson. 1985. Floral biology and regulation of seed set and seed size in the lily, Clintonia borealis. American Journal of Botany 72: 1544-1552.

HALDANE, J. B. S. 1932. The causes of evolution. Princeton University Press, Princeton, NJ.

HAWKes, M. W. 1990. Reproductive strategies. In K. M. Cole and R. G. Sheath [eds.], Biology of the red algae, 455-476. Cambridge University Press, Cambridge.

HILL, J. P., AND E. M. LORD. 1986. Dynamics of pollen tube growth in the wild radish, Raphanus raphanistrum (Brassicaceae). I. Order of fertilization. Evolution 40: 1328-1333.

Hommersand, M. H., AND S. FredericQ. 1990. Sexual reproduction and cystocarp development. In K. M. Cole and R. G. Sheath [eds.], Biology of the red algae, 305-345. Cambridge University Press, Cambridge.

Hossaert, M., AND M. VAlero. 1988. Effect of ovule position in the pod on patterns of seed formation in two species of Lathyrus (Leguminosae: Papillionaideae). American Journal of Botany 75: 17141731.

JOHNSTON, M. O. 1992. Effects of cross and self-fertilization on progeny fitness in Lobelia cardinalis and L. siphilitica. Evolution 46: 688702.

KLING, R., AND M. Bodard. 1987. Morphogenesis of the frond of Gracilaria verrucosa (Hudson) Papenfuss: the differentiation of vegetative and sexual areas. Proceedings of the XIIth International Seaweed Symposium 12: 205-206.

LABEYRIE, V., AND D. RoJAS-RousSE. 1985. Super parasitism reconsidered: is it an adaptive competition? Example of Diadromus pulchellus. Esperimentia 41: 15-18.

Lefebvre, C., C. Destombe, AND J. Godin. 1987. Le fonctionnement du carposporophyte de Gracilaria verrucosa et ses répercussions sur la stratégie de reproduction. Cryptogamie, Algologie 8: 113-126.

LEVIN, D. A. 1984. Inbreeding depression and proximity-dependent crossing success in Phlox drummondii. Evolution 38: 116-127. . 1989a. Proximity dependent cross-compatibility in Phlox. Evolution 43: 1114-1116.
. 1989b. Inbreeding depression in partially self-fertilizing Phlox. Evolution 43: 1117-1123.

- AND K. Clay. 1985. Extraneous pollen advantage in Phlox cuspidata. Heredity 54: 145-148.

- AND H. W. Kerster. 1974. Gene flow in seed plants. Evolutionary Biology 7: 138-220.

Lyons, E. E., N. M. Waser, M. V. Price, J. Antonovics, AND A. F. MOTTEN. 1989. Sources of variation in plant reproductive success and implications for concepts of sexual selection. The American Naturalist 134: 409-433.

MARSHALL, D. L. 1988. Postpollination effects on seed paternity: mechanisms in addition to microgametophyte competition operate in wild radish. Evolution 42: 1256-1266.

. 1991. Nonrandom mating in wild radish: variation in pollen donor success and effects of multiple paternity among one- to sixdonor pollinations. American Journal of Botany 78: 1404-1418.

- AND N. C. Ellstrand. 1986. Sexual selection in Raphanus sativus: experimental data on non-random fertilization, maternal choice, and consequences of multiple paternity. The American Naturalist 127: 446-461.

AND - 1988. Effective mate choice in wild radish: evidence for selective seed abortion and its mechanism. The American Naturalist 131: 739-756.

- AND M. W. Folsom. 1991. Mate choice in plants: an anatomical to population perspective. Annual Review of Ecology and Systematics 22: 37-63.

- AND K. L. WhITTAKER. 1989. Effects of pollen donor identity on offspring quality in wild radish, Raphanus sativus. American Journal of Botany 76: 1081-1088.

MAZER, S. J. 1987. The quantitative genetics of life history and fitness components in Raphanus raphanistrum L. (Brassicaceae): ecological and evolutionary consequences of seed weight variation. The American Naturalist 130: 891-914.

McCall, C., T. Mitchell-Olds, AND D. M. Waller. 1991. Distance between mates affects seedling characters in a population of $\mathrm{Im}$ patiens capensis (Balsaminaceae). American Journal of Botany 78: 974-970.

Mclachlan, J., J. P. van der Meer, and N. L. Bird. 1977. Chromosome numbers of Gracilaria foliifera and Gracilaria sp. (Rhodophyta) and attempted hybridizations. Journal of the Marine Biological Association of the United Kingdom 57: 1137-1 141.

Mitchell-Olds, T., AND R. G. Shaw. 1987. Regression analysis of natural selection: statistical inference and biological interpretation. Evolution 41: 1149-1161.

Mulcahy, D. L., P. S. Curtis, ANd A. A. Snow. 1983. Pollen competition in a natural population. In C. E. Jones and R. J. Little [eds.], Handbook of experimental pollination biology, 330-337. Van Nostrand Reinhold, New York, NY.

Nakamura, R. P., AND N. C. Wheeler. 1992. Pollen competition and paternal success in Douglas-fir. Evolution 46: 846-851.

NewPORT, M. E. A. 1989. A test for proximity-dependent outcrossing in the alpine skypilot, Polemonium viscosum. Evolution 43: 11101113.

PALUMBI, S. R. 1992. Marine speciation on a small planet. Trends in Ecology and Evolution 7: 114-118.

PARKER, M. A. 1992. Outbreeding depression in a selfing annual. Evolution 46: 837-841.

Pittman, K. E., AND D. A. Levin. 1989. Effects of parental identities and environment on components of crossing success in Phlox.drummondii. American Journal of Botany 76: 409-418.

Plastino, E. M., AND E. C. DE Oliveira. 1988. Sterility barriers among species of Gracilaria (Rhodophyta, Gigartinales) from the Sao Paulo Littoral, Brazil. British Phycological Journal 23: 267-271.

Price, M. V., AND N. M. WASER. 1979. Pollen dispersal and optimal outcrossing in Delphinium nelsonii. Nature 277: 294-296.

Queller, D. C. 1987. Sexual selection in flowering plants. In J. W. Bradbury and M. B. Andersson [eds.], Sexual selection: testing the alternatives, 165-179. John Wiley \& Sons, Chichester.

Redmond, A. M., L. E. Robbins, AND J. Travis. 1989. The effects of pollination distance on seed production in three populations of Amianthum muscaetoxicum (Liliaceae). Oecologia 79: 260-264.

RICE, E. L., AND C. J. BIRD. 1990. Relationships among geographically 
distant populations of Gracilaria verrucosa (Gracilariales, Rhodophyta) and related species. Phycologia 29: 501-510.

Ritland, K., AND F. R. GANDERs. 1987. Crossability of Mimulus guttatus in relation to components of gene fixation. Evolution 41: 772-786.

RoACH, D. A., AND R. D. WulfF. 1987. Maternal effects in plants. Annual Review of Ecology and Systematics 18: 209-235.

RuSSELL, G. 1986. Variation and natural selection in marine macroalgae. Oceanography and Marine Biology Annual Review 24: 309377.

SANTElices, B. 1990. Patterns of reproduction, dispersal and recruitment in seaweeds. Oceanography and Marine Biology Annual Review 28: 177-276.

Sari Gorla, M., C. Frova, G. Binelli, and E. Ottaviano. 1986. The extent of gametophytic-sporophytic gene expression in maize. Theoretical and Applied Genetics 72: 42-47.

SAS InSTITUTE, INC. 1988. SAS/STAT $\times$ user's guide, Release 6.03 . Cary, NC.

Schemske, D. W., AND L. P. PAutler. 1984. The effects of pollen composition on fitness components in a neotropical herb. Oecologia 62: 31-36.

Schlichting, C. D., AND B. Devlin. 1989. Male and female reproductive success in the hermaphroditic plant Phlox drummondii. The American Naturalist 133: 212-227.

SEARLES, R. B. 1980. The strategy of the red algal life history. The American Naturalist 115: 113-120.

SHIELDS, W. M. 1982. Philopatry, inbreeding, and the evolution of sex. State University of New York Press, Albany, NY.

SobreVILA, C. 1988. Effect of distance between pollen donor and pollen recipient on fitness components in Espeletia schultzii. American Journal of Botany 75: 701-724.

SoKAL, R. R., AND R. J. RoHLF. 1981. Biometry, 2d ed. W. H. Freeman, San Francisco, CA.

SteARNS, S. C. 1987. The selection-arena hypothesis. In S. C. Stearns [ed.], The evolution of sex and its consequences, 337-349. Birkhäuser Verlag, Basel.

TANKSLEY, S. D., D. ZAMIR, AND C. M. RICK. 1981. Evidence for extensive overlap of sporophytic and gametophytic gene expression in Lycopersicon esculentum. Science 213: 453-455.

VALERO, M., AND I. OlivierI. 1985. Adjacent populations of cocksfoot (Dactylis glomerata L.): a detailed study of allozyme variation across contrasting habitats. In P. Jacquard, G. Heim, and J. Antonovics [eds.], Genetic differentiation and dispersal in plants, 339-354. Springer-Verlag, Basel.

, S. Richerd, V. Perrot, AND C. Destombe. 1992. Evolution of alternation of haploid and diploid phases in life cycles. Trends in Ecology and Evolution 7: 25-29.

WASER, N. M., AND M. V. PRICE. 1983. Optimal and actual outcrossing in plants, and the nature of plant-pollinator interaction. In C. E. Jones and R. J. Little [eds.], Handbook of experimental pollination biology, 341-359. Van Nostrand Reinhold, New York, NY.

- AND - 1985. Reciprocal transplant experiments with Delphinium nelsonii (Ranunculaceae): evidence for local adaptation. American Journal of Botany 72: 1726-1732.

- AND - 1989. Optimal outcrossing in Ipomopsis aggregata: seed set and offspring fitness. Evolution 43: 1097-1 109. , AND - 1991a. Outcrossing distance effects in Delphinium nelsonii: pollen loads, pollen tubes, and seed set. Ecology 72: 171179.

, AND —. 1991b. Reproductive costs of self-pollination in Ipomopsis aggregata (Polemoniaceae): are ovules usurped? American Journal of Botany 78: 1036-1043.

,-- A. M. Montalvo, and R. N. Gray. 1987. Female mate choice in a perennial herbaceous wildflower, Delphinium nelsonii. Evolutionary Trends in Plants 1: 29-33.

WRIGHT, S. 1943. Isolation by distance. Genetics 28: 114-138.

YAMANOUCHI, S. 1906. The life history of Polysiphonia violacea (Preliminary note). Botanical Gazette 41: 425-433.

APPENDIX. Experimental crossing design: number of crosses performed for each crossing combination, in the four sets of crosses. Distinct numbers refer to distinct individuals in the same population, i.e., same site and same tidal level (numbering is independent for males and females, and for different populations). When only some of the crossing combinations are realized, as in cross set 2 and 3 , mates were randomly chosen according to a balanced design.

\begin{tabular}{|c|c|c|c|c|c|c|c|c|c|c|c|c|}
\hline \multicolumn{13}{|c|}{ Cross set 1: Intrapopulation crosses } \\
\hline \multicolumn{6}{|c|}{ Within Audresselles low population (50 crosses) } & \multicolumn{7}{|c|}{ Within Gris-Nez low population (96 crosses) } \\
\hline \multirow[b]{2}{*}{ Females } & \multicolumn{4}{|c|}{ Males } & & \multirow[b]{2}{*}{ Females } & \multicolumn{6}{|c|}{ Males } \\
\hline & 1 & 2 & 4 & 5 & 8 & & 1 & 2 & 3 & 4 & 5 & 6 \\
\hline 1 & 2 & 2 & 2 & 2 & 2 & 1 & 3 & 3 & 3 & 3 & 3 & 3 \\
\hline 2 & 2 & 2 & 2 & 2 & 2 & 2 & 3 & 3 & 3 & 3 & 3 & 3 \\
\hline 4 & 2 & 2 & 2 & 2 & 2 & 3 & 3 & 3 & 3 & 3 & 3 & 3 \\
\hline 6 & 2 & 2 & 2 & 2 & 2 & 4 & 3 & 3 & 3 & 3 & 3 & 3 \\
\hline \multirow[t]{2}{*}{7} & 2 & 2 & 2 & 2 & 2 & 5 & 2 & 2 & 2 & 2 & 2 & 2 \\
\hline & & & & & & 6 & 2 & 2 & 2 & 2 & 2 & 2 \\
\hline
\end{tabular}

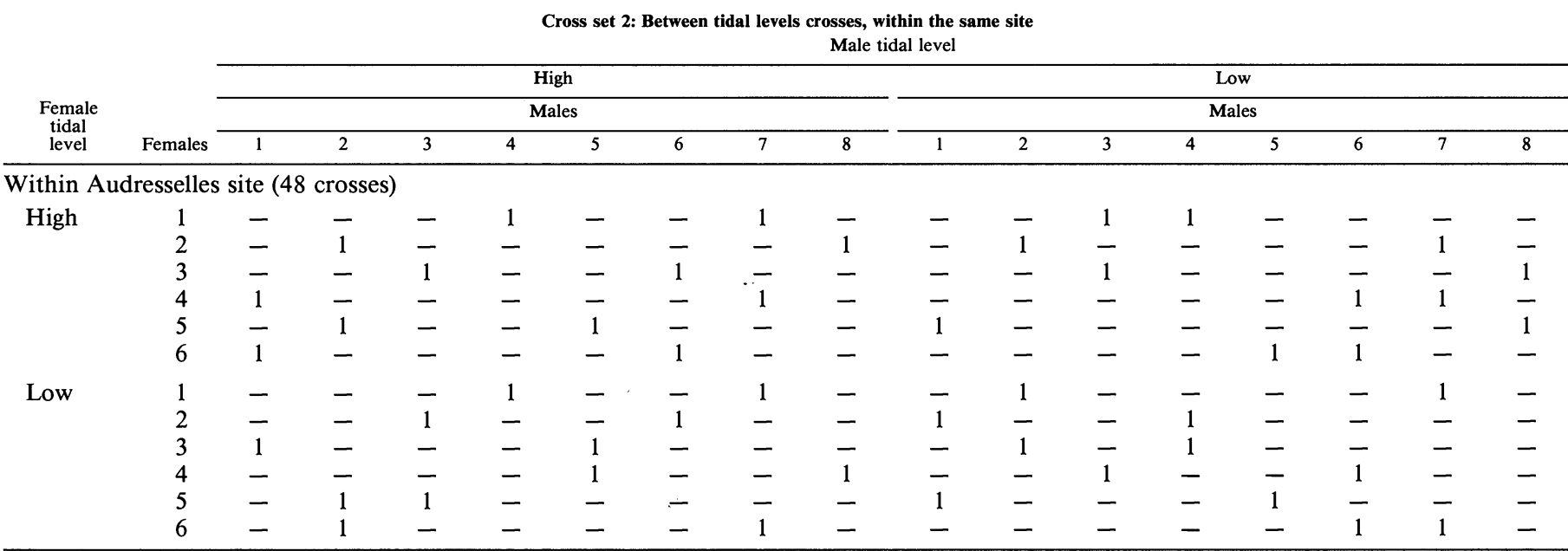


APPENDIX. Continued.

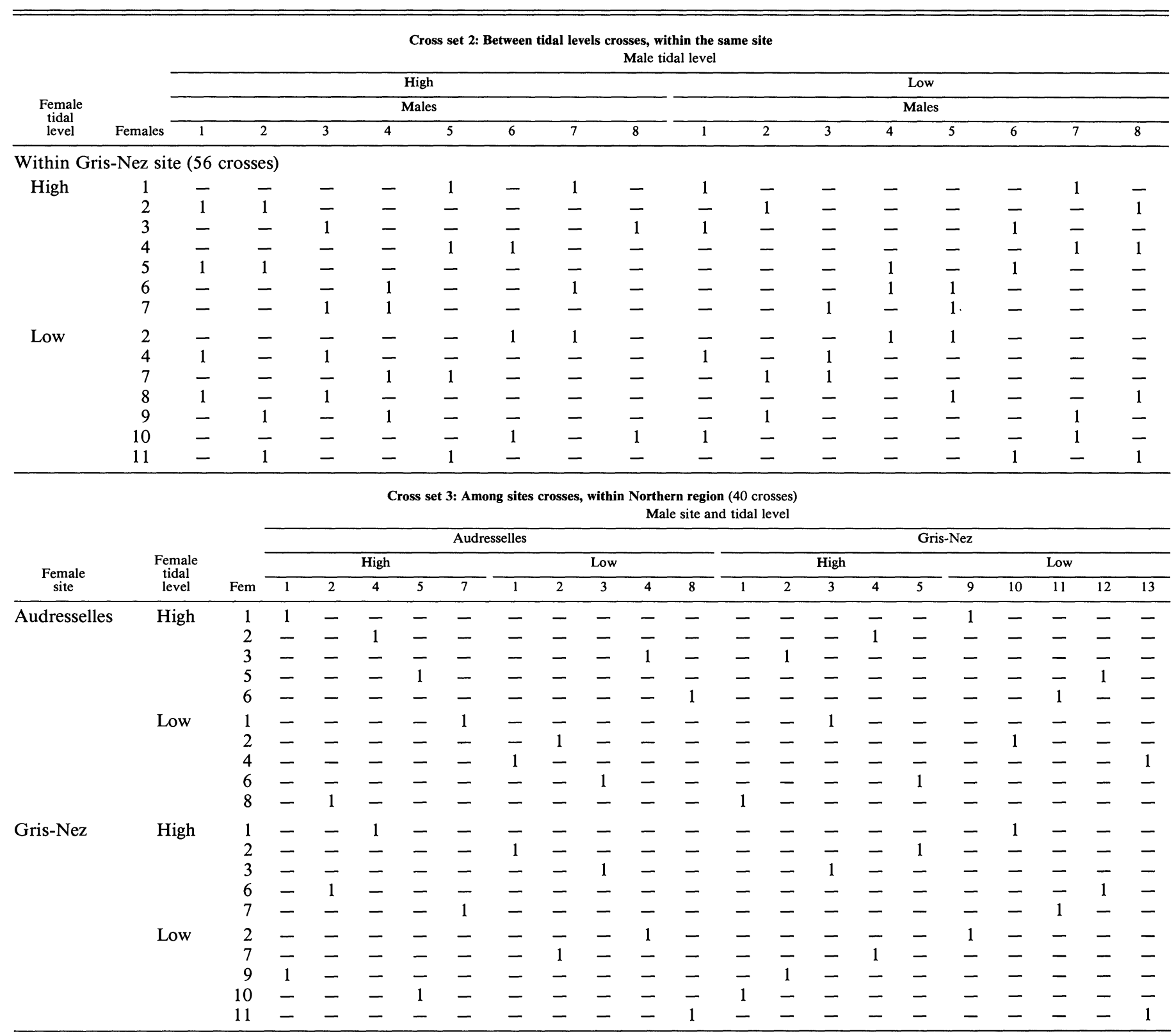

Cross set 4: Among region crosses (81 crosses)
Male region

